\section{Hanyang Medical R evi iews}

Hanyang Med Rev 2013;33:83-89

http://dx.doi.org/10.7599/hmr.2013.33.2.83

pISSN 1738-429X eISSN 2234-4446

\section{세포 내 산화환원신호에서의 자식작용}

\author{
최태규 · 김성수
}

경희대학교 의과대학 생화학분자생물학교실

\title{
Autophagy in Redox Signalling
}

\author{
Tae Gyu Choi, Sung Soo Kim \\ Department of Biochemistry and Molecular Biology, School of Medicine, Kyung Hee University, Seoul, Korea
}

\begin{abstract}
Autophagy is a major catabolic process that is involved in cellular degradation of unnecessary or dysfunctional cellular components via the lysosomal machinery. Autophagy is involved in a variety of biological processes such as programmed cell death, removal of damaged organelles and development of different tissue-specific functions. In recent experiments, the role of autophagy as an important mediator of the pathological response to redox signalling of cellular damage has been elucidated and expanded. Oxidative stresses to the cellular system induces autophagy as a means to selectively remove oxidatively modified macromolecules and organelles. Reactive oxygen species (ROS) are highly reactive oxygen free radicals that are produced as by-products of cellular metabolism, primarily by mitochondria and NADPH oxidases. ROS can be beneficial or harmful to cells and tissues by depending on their concentration and location. ROS function as redox messengers in intracellular signalling at physiologically low level, whereas excess ROS can induce oxidative modification of cellular macromolecules and eventually promote cell death. Thus, the interface of autophagy-related oxidative stress adaptation and cell death is important for understanding redox biology and pathogenesis. In this review, we describe the basic mechanism and function of autophagy in the context of response to oxidative stress and redox signalling in pathogenesis.
\end{abstract}

Key Words: Autophagy; Cell Death; Reactive Oxygen Species; Oxidation-Reduction

\author{
Correspondence to: Sung Soo Kim \\ 우130-701, 서울 동대문구 경희대로 26, \\ 경희대학교 의과대학 생화학분자생물학 \\ 교실 \\ Department of Biochemistry and Molecu- \\ lar Biology, School of Medicine, Kyung \\ Hee University, 26 Kyunghee-daero, \\ Dongdaemun-gu, Seoul 130-701, Korea \\ Tel: +82-2-961-0524 \\ Fax: $+82-2-959-8168$ \\ E-mail: sgskim@khu.ac.kr \\ Received 12 March 2013 \\ Revised 22 April 2013 \\ Accepted 26 April 2013 \\ This is an Open Access article distributed under
the terms of the Creative Commons Attribution
Non-Commercial License (http://creativecom-
mons.org/licenses/by-nc/3.0) which permits un-
restricted non-commercial use, distribution, and
reproduction in any medium, provided the origi-
nal work is properly cited.
}

\section{서 론}

자식작용(autophagy 또는 autophagocytosis)은 리소좀을 통하 여 불필요하거나 기능을 제대로 하지 못하는 세포 내 구성물질을 분해하는 주요한 이화작용의 하나이다[1]. 자식작용은 대부분의 조직에서 기본적으로 발생하는 현상이며 세포기관과 단백질 등의 합성과 분해 사이의 균형, 즉 전환율을 조절하여 다양한 기관에서 개체발생, 세포분화 또는 조직재형성을 조절한다[2]. 자식작용은 세포 내 당과 아미노산의 결핍 그리고 저산소증, 산화적 스트레스, 화학치료제제의 사용 등에 의해서도 일어나며[3]. 최근에는 세포신 호 및 단백질손상에 대해 활성산소와 상호작용하는 것으로 알려
져 있다. 최근에는 신경변성질환인 알츠하이머병과 파킨슨병, 헌팅 턴병 그리고 암, 당뇨병, 심혈관계질환, 염증반응 등과 같은 다양한 병리학적 현상에서 중간매개자의 역할을 하는 것으로 주목 받고 있다[3].

활성산소는 산소이온과 과산화물을 포함하는 화학적으로 반응 성이 높은 분자를 일컬으며 산소대사과정에서 발생하는 정상적인 부산물로 과산화수소 $\left(\mathrm{H}_{2} \mathrm{O}_{2}\right)$ 와 초과산화물 $\left(\mathrm{O}_{2}{ }^{-}\right)$, 수산화이온 $(\bullet \mathrm{OH})$ 등이 그 대표적인 예이다. 활성산소는 신호전달물질로서 세 포신호전달과 항상성에 반드시 필요한 산화환원신호의 매개체가 되지만 과도한 활성산소의 발생은 미토콘드리아 기능장애나 산화 적 스트레스, 단백질응집, 자식작용 등을 일으킴으로써 다양한 질 
병과 연관되어 있다[4]. 자식작용과 산화환원신호 그리고 활성산소 의 상관관계에 대한 기전이 아직은 명확하지 않으나, 산화환원신호 의 조절장애는 자식작용 활성을 떨어뜨릴 수 있으며 자식작용의 활성저해는 비기능적 단백질의 잔류와 미토콘드리아 기능장애로 이어져 보다 심각한 산화적 스트레스를 유도하게 된다는 것이 통설 이다[5].

\section{본 론}

\section{1. 자식작용의 기전}

자식작용은 단백질이 리소좀에 도달하는 방법에 따라 거대자식 작용(macroautophagy) 그리고 미세자식작용(microautophagy), 샤페론 매개자식작용(chaperon-mediated autophagy)의 세 가지 로 분류된다. 첫째, 거대자식작용은 일반적인 자식작용을 일컬으 며 자가포식소포체(autophagosome)로 알려진 이중막 소포체를 형 성하는 다단계 과정을 거친다. 자가포식소포체가 성숙되면 리소좀 과 융합하여 자가포식용해소체(autophagolysosome)를 형성하고 산성가수분해효소에 의해 매개되는 산성환경에서 포집된 구성물 을 분해시킨다. 이 과정에서 30 여 개의 자식작용 연관유전자(autophagy-related gene, Atg)가작용하며 이들 유전자는 효모에서부 터 인간에 이르기까지 매우 유사하다[6]. 둘째, 미세자식작용은 지 질막회선에 의해 리소좀이 직접 세포구성물을 포획하고 삼키는 과 정을 말한다. 셋째, 샤페론 매개자식작용은 해당 샤페론이 표적단 백질 내의 5 개 펩타이드, $\mathrm{KFERQ}$ 를 인지하여 샤페론-단백질복합 체를 형성한 후 당복합체가 리소좀막 상에서 lysosome-associated membrane protein-2A receptor (LAMP-2A)와 결합하여 리소좀 내부로 전위, 분해되는 과정이다.

본 논문에서는 자식작용 중 선택적인 Atg 단백질과의 조합에 의 해 이루어지는 거대자식작용에 초점을 맞추어 설명하도록 할 것이 다. 거대자식작용의 주요단계는 활성산소와 활성산소 대사체에 의 해 조절되는 것으로 알려져 있으며, 자식작용에 대한 활성산소의 영향에 대해 알아보기 위해 분자적 기전 및 해당요소를 먼저 요약 하고자 한다. 포유류의 세포에서 열량결핍에 의해 mammalian target of rapamycin (mTOR)의 활성이 억제되면, Atg13의 탈인산 화가 발생한다. 탈인산화된 Atg13은 ULK1 그리고 2 [(uncoordinated family member)-51-like kinase 1과 2, Atg1 동족체]와 결합 하여 활성화시킴으로써 효모 Atg17의 이종상동체인 focal adhesion kinase family-interacting protein of $200 \mathrm{kDa}$ (FIP200)과 활성 복합체를 형성한다. ULKs-Atg13-FIP200 복합체는 자식작용분리 막(isolation membrane)을 신장시켜 자가포식소포체를 완성한다 (Fig. 1)[6]. 전 자가포식소포체구조를 형성하기 위해 beclin-1-class III phosphoinositide 3-kinase (PI3K) 복합체뿐만 아니라 light chain 3-II (LC3-II)의 생성 및 자가포식소포체(autophagosomal mem-

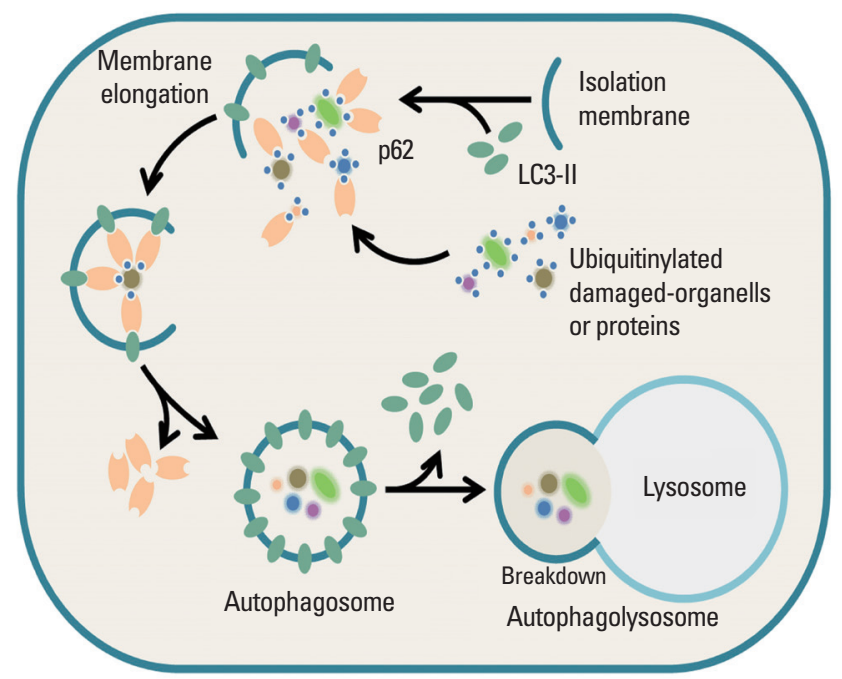

Fig. 1. Schematic diagram of the steps of autophagy. Autophagy is initiated by the formation of the isolation membrane. The concerted action of the autophagy core machinery proteins at the phagophore assembly site (PAS) is thought to lead to the expansion of the isolation membrane into an autophagosome (vesicle elongation). Ubiquitinylated proteins may be directly targeted for degradation via the autophagic pathway. The $\mathrm{p} 62$ protein interacts with ubiquitinylateddamaged proteins in cells. The complex is then selectively tied to the autophagosome through the interaction between p62 and light chain 3-II (LC3-II). When the outer membrane of the autophagosome fuses with a lysosome, it forms an autophagolysosome. Finally, the sequestered material is degraded inside the autophagolyosome and recycled.

brane) 삽입이 필요하다[7]. LC3 (또는 Atg8)은 유비퀴틴형 단백질 이며 이때 LC3-I은 단백질 번역 후 변형과정을 거친다. 신생 단백질 $\mathrm{LC} 3$ 는 단백질 분해효소 $\operatorname{Atg} 4$ 에 의해 C-말단 인접부위가 절단되 어 LC3-I이 되고 이로 인해 C-말단 글리신 잔기가 노출된다. LC3-I 은 phosphatidylethanolamine (PE)에 의해 LC3-II로 변형된다. 이 과정은 Atg7 (E1형 활성효소) 그리고 Atg3 (E2형 접합효소), At$\mathrm{g} 16 \mathrm{~L}$ (E3형 연결효소) 복합체에 의해 매개되는 유비퀴틴화 형태의 반응을 포함한다. 우선, Atg7은 Atg10을 Atg12에 그리고 Atg3를 LC3-I에 접합시키는 역할을 담당한다. 다음, E2형 효소인 Atg3와 $\operatorname{Atg} 10$ 가 Atg5의 Atg12에 대한 접합을 이화시키면 LC3-I은 PE에 접합되어 LC3-II로 전환된다. 이러한 접합과정은 자가포식소포체 의 형성에 필수적이다[8].p62 [또는 sequestosome 1 (SQSTM1)] 단 백질은 유비퀴틴 결합부위(ubiquitin-associated domain, UBA)를 가지고 있으며 이를 통해 유비퀴틴화된 단백질과 결합할 수 있다. 이 후 자가 올리고머화를 통해 결합된 단백질을 기능적으로 격리시 키고 이 유비퀴틴화 단백질-p62 올리고머 복합체는 자가포식소포 체에 결합되어 있는 LC3와 결합하여 최종적으로 $\mathrm{p} 62$ 를 포함하는 자가포식소포체 내의 단백질과 세포기관은 리소좀 내에서 분해된 다(Fig. 1)[9]. 


\section{2. 산화환원신호에 의한 자식작용의 조절}

활성산소의 발생에 따라 자식작용의 활성이 조절된다는 것은 잘 알려져 있다. 활성산소는 산소대사과정에서 불완전한 산소의 환원 과정에 의해 파생된 분자로 그 발생 특이적 기전과 세포 내 표적을 갖고 있다. 생물학적으로 가장 중요한 활성산소는 과산화수소와 초과산화물이며 세포 내 신호를 조절하는 요소에 해당한다. 과산 화수소와 초과산화물은 산화질소( $\mathrm{NO})$ 와 상호작용하여 과산화 질소 $(\mathrm{ONOO})$ 와 같은 활성질소와 산화지질과 같은 활성지질(reactive lipid species)을 발생시킬 수 있다[10]. 과산화수소와 초과산화 물의 주요한 세포 내 발생원은 미토콘드리아 전자전달계와 세포막 에 존재하는 nicotinamide adenine dinucleotide phosphate (NA$\mathrm{DPH}$ ) oxidase 그리고 상대적으로 저준위의 활성산소를 생산하는 과산화소체와시토크롬 p-450 시스템이다[11].

\section{1) 산화환원신호에 의한 자식자용의 유도}

아미노산의 결핍은 Class III PI3K 의존적으로 미토콘드리아의 과산화수소 발생을 유도하여 자식작용을 일으킨다. 특히 Atg4의 이화작용부위에 인접한 시스테인81은 과산화수소에 의한 산화작 용의 표적이다. Atg4의 시스테인 81 의 산화형은 $\operatorname{Atg} 4$ 의 단백질 분해 능을 불활성화시켜 Atg4에 의한 LC3의 C-말단가공을 저해하여 탈지질화를 억제시키고 결과적으로 자가포식소포체의 형성을 증 가시킨다. 그러나 Atg4의 시스테인81의 환원형은 Atg4로 하여금 $\mathrm{LC} 3$ 를 탈지질화시킴으로써 활성화 상태로 만들어 자기포식소포 체형성을 억제한다[12].

한편, mTOR의 열량의존적 활성은 이형이량체인 $5^{\prime}$ adenosine monophosphate-activated protein kinase (AMPK)에 의해 조절되 며 이는 높은 세포 내 AMP/ATP (5' adenosine triphosphate) 비율 에 반응하는 인산화에 의해 활성화된다. 영양결핍 상태에서 활성 AMPK는 mTORC1 (mTOR Complex 1)의 소단위체인 regulatoryassociated protein of mTOR (Raptor)와 tuberous sclerosis protein 2 (TSC2)를 인산화시켜 $\mathrm{mTORC} 1$ 의 활성화를 억제하여 자식작용 을 일으킨다[13]. 보다 최근 연구에서는 AMPK가 당결핍상태에서 $\mathrm{ULK1}$ 를 세린317과 세린777 인산화를 통해 활성화시키며[14], 간세 포에서는 인산화된 ULK1 (세린555)가 나타나지만 혈당강하제의 하나로 $\mathrm{AMPK}$ 를 활성화시키는 metformin을 처리한 $\mathrm{AMPK}^{-/}$마우 스에서는 ULK1의 인산화가 일어나지 않는다고 보고되어 있다[15]. 뿐만 아니라 마우스의 배아 섬유아세포에서 인위적 ULK1 유전자 의 발현 억제는 미토콘드리아 특이적 자식작용의 유도를 통해 열량 결핍상태가 일으키는 세포생존율을 보존하였다[15]. AMPK는 활 성산소에 의한 자식작용의 주요 매개체이며 이는 과산화수소에 의 해 유도되는 산화적 스트레스에 감응하여 AMPK $\alpha 1$ 이화 소단위 체의 트레오닌172의 인산화를 통해 이루어진다. AMPK는 저산소 증이 일으키는 미토콘드리아 활성산소에 반응하여 AMP/ATP 비
율이 아닌 Atg5와 liver kinase B1 (LKB1) 또는 serine/threonine kinase 11 (STK11) 단백질 의존적으로도 자식작용을 일으킬 수 있다 [16]. 활성산소에 의한 자식작용의 유도는 DNA 손상에 대한 세포 반응에서 중요한 역할을 담당하는 ataxia-telangiectasia mutated (ATM) 단백질에 의해서도 매개되며, LKB1/AMPK 대사경로를 통 해 세포질 내 TSC2의 활성을 증가시켜 $\mathrm{mTORC} 1$ 의 불활성화를 초 래한다[17].

핵단백질인 high mobility group box 1 (HMGB1)는 시토카인과 외상(trauma), 세포자멸사에 반응하여 세포 외로 방출되어 receptor for advanced glycation end products (RAGE) 그리고 toll-like receptor (TLR) 등의 세포수용체에 결합하여 염증반응을 매개할 수 있다[18]. HMGB1은 활성산소 의존적으로 핵에서 세포질로 이 동하여 Beclin1-Bcl2 상호작용과 extracellular regulated kinase 1/2 (ERK1/2)의 활성을 중단시켜 자식작용을 약화시킨다. 항산화제인 $\mathrm{N}$-acetyl cysteine (NAC)을 처리한 경우 SOD1 또는 2 [superoxide dismutase 1 (Cu-ZnSOD) 또는 $2(\mathrm{MnSOD})]$ 가 유도하는 자식작용 및 $\mathrm{HMGB1}$ 의 세포질 이동이 억제된다[19].

저산소증에 의한 미토콘드리아 활성산소는 hypoxia-inducible

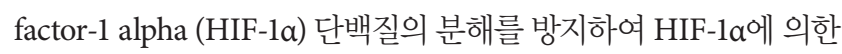
다양한 표적유전자의 전사를 유도하는데, 이중 BCL2/adenovirus E1B $19 \mathrm{kDa}$ protein-interacting protein 3 (BNIP3) 또는 BNIP3like (BNIP3L)는 저산소 상태에 의해 발생하는 자식작용의 유도에 중요한 역할을 담당한다[20]. 과산화수소에 의한 BNIP3 매개 자식 작용은 $\mathrm{mTOR}$ 의 세린 2481 잔기의 탈인산화를 통해 발생하며[21], 저산소증이 유도하는 자식작용은 BNIP3의 mTORC1 조절인자인 Rheb (GTPase의 하나)과 결합하여 억제함으로써 결국 mTORC1 의 활성화를 방해하여 이루어진다[22]. 또한, BNIP3의 시스테인64 의 인위적 돌연변이는 허혈/재관류 등으로 유발된 산화적 스트레 스 시 발생하는 BNIP3의 동형이량체 형성을 약화시켜 자식작용에 중요한 역할을 담당하는 LC3와 BNIP3의 상호작용을 억제한다[23]. Fig. 2에서 활성산소와 자식작용과의 관계를 모식하였다(Fig. 2).

\section{2) 자식작용과 산화환원신호의 상호작용}

활성산소에 의한 전사 후 단백질변형과 산화환원신호 관련 전사 인자에 의한 항산화단백질의 유도는 자식작용과 항산화적 방어를 포함하는 세포 내 전반의 유전자발현 양상을 변화시킨다. 활성산 소에 반응하는 중요한 산화환원신호경로 중 하나는 nuclear factor-erythroid 2-related factor 2 (Nrf2)/kelch-like ECH-associated protein 1 (Keapl) 경로이다. Nrf2는 특정유전자의 촉진부위의 항 산화반응인자(antioxidant response element, ARE) 또는 전자친화 반응요소(electrophile response element, ERE)와 결합하여 항산화 유전자의 발현을 조절한다[24]. Nrf2는 p62의 발현을 증가시킴으 로써 자식작용을 활성화시켜 일반적인 혹은 활성산소에 의한 손상 
단백질의 분해를 촉진한다[25]. Nrf2는 정상상태에서 산화환원감 지단백질인 Keap1의 Neh2 (Nrf2-ECH homology 2) 부위와 결합 하여 불활성화 상태로 세포질 내에 존재하나 산화적 스트레스에 의해 Keap1으로부터 분리되어 핵으로 이동, 활성화되어 $\mathrm{NADPH}$ quinone acceptor oxidoreductase 1 (NQO1) 그리고 glutathione transferase (GST)와 같은 항산화단백질의 전사를 유도한다[26] 따라서 자식작용은 활성산소에 의한 세포신호에 반응하는 전사적 기전에 의해서도 조절된다고 말할 수 있다.

활성산소에 반응하는 두 번째 전사인자는 p53이다. p53은 활성

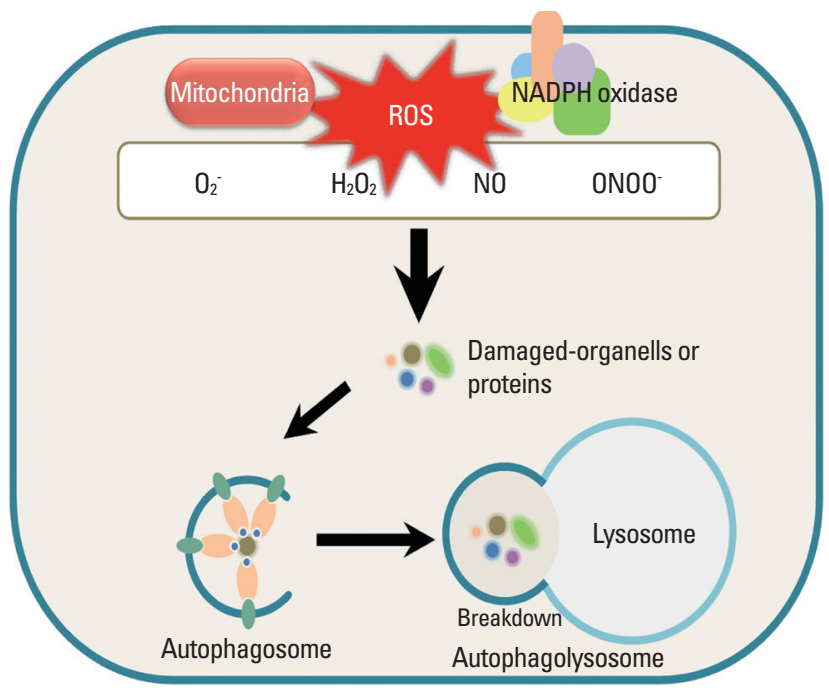

Fig. 2. Reactive oxygen species-induced autophagy. ROS production can induce protein aggregates, generated by the mitochondrial electron transport chain activities and by NADPH oxidase. These $\mathrm{ROS}$, which include hydrogen superoxide $\left(\mathrm{O}_{2}{ }^{-}\right)$, peroxide $\left(\mathrm{H}_{2} \mathrm{O}_{2}\right)$, nitric oxide ( $\mathrm{NO})$, peroxynitrite $\left(\mathrm{ONOO}^{-}\right)$, can damage proteins and celluar organelles to stimulate autophagy. Atg $4 \mathrm{Cys}^{81}$ thiol modification is involved in $\mathrm{H}_{2} \mathrm{O}_{2}$-induced autophagy. S-nitrosation of inhibitor of кB kinase $\beta$ (IKK $\beta$ ) and c-Jun N-terminal kinase1 (JNK1) are involved in NO-induced inhibition of autophagy. Hypoxia-induced ROS also activates autophagic pathway by hypoxia inducible factors (HIFs) and their adapt proteins. Moreover, autophagy can stimulate the ROS generation to enhance the autophagic signalling.
산소에 반응하여 그 발현량이 증가하며 활성산소의 양을 증가시키 거나 감소시킬 수 있는 표적단백질의 전사를 조절한다. 뿐만 아니 라 p53은 자식작용을 약화시키거나 증가시킬 수 있는 유전자의 발 현을 모두 조절한다[27]. p53의표적 단백질 중 하나인 TP53-induced glycolysis and apoptosis regulator (TIGAR)는 과당-2,6-이 인산가수분해효소의 활성을 가지며 해당과정을 감소시킨다. 또한 $\mathrm{NADPH}$ 의 양을 증가시키며 glutathione (GSH)/glutathione disulfide (GSSG) 비율을 증가시키고 p53이 유도하는 세포 내 활성산소 의 양을 감소시킬 수 있다[28]. TIGAR의 과발현은 저산소증 또는 당결핍이 유도하는 자식작용을 약화시킨다[29]. 또 다른 p53 조절 유전자인 damage-regulated autophagy modulator (DRAM)은 자 식작용을 증진시킨다[30]. 유사하게 p53 단백질에 의해 전사조절 되는 sestrin 단백질은 AMPK-mTOR 신호경로를 통해 자식작용 을 일으킴으로써 세포의 산화적 스트레스를 억제하는 것으로 알려 져 있다[31].

\section{3. 병리학적 기전에서의 자식작용과 산화환원신호}

자식작용은 단순히 기능을 다한 단백질과 세포소기관을 분해시 켜 세포로 하여금 필요한 물질을 재생산할 수 있게 조력하는 세포 생물학적 기전의 하나로 여겨져 왔으나 최근에는 신경변성질환인 알츠하이머병과 파킨슨병, 헌팅턴병 그리고 암, 당뇨병, 염증반응 등과 같은 다양한 질병과 병리학적 현상에서 중요한 역할이 밝혀지 고 있다. 다음에서 자식작용의 병리학적 역할에 대하여 알아보겠 다(Table 1).

\section{1) 신경변성질환에서의 자식작용}

자식작용은 특정 신경변성질환에서 세포보호능을 통해 신경세 포의 세포사멸을 억제하는 것으로 알려져 있다. 단백질 응집체의 축적은 정상적인 신경세포의 기능을 방해하며 세포독성을 나타낸 다[32]. 자식작용은 신경변성질환에서 나타날 수 있는 다음과 같은 비정상적 단백질의 분해와 연관성을 나타낸다. 헌팅턴병을 일으키 는 헌팅턴 단백질(huntington, $\mathrm{Htt}$ ) 내의 글루타민 다량체의 확장 그리고 파킨슨병을 유도하는 $\alpha$-synuclein, 전측두엽치매와 연관하

Table 1. Roles of autophagy in disease and pathogenesis

\begin{tabular}{|c|c|c|}
\hline $\begin{array}{l}\text { Disease or pathological } \\
\text { state }\end{array}$ & Beneficial effects of autophagy & Hamful effect of autophagy \\
\hline Neurodegeneration & Allows the removal of aggregated proteins before they are toxic. & Induce cell death in neurons that accumulate aggregated proteins. \\
\hline Cancer & Promote cell death as a tumor suppressor & Prevent cell death as an oncogenic mechanism. \\
\hline Diabetes & $\begin{array}{l}\text { Necessary to maintain structure, mass, and function of } \beta \text {-cells } \\
\text { and affect insulin sensitivity }\end{array}$ & $\begin{array}{l}\text { Aging is associated with impaired glucose tolerance, decline of autophagic } \\
\text { activity may be involved in age-associated reduction of glucose tolerance. }\end{array}$ \\
\hline Cadiovascular diseases & Compensate for defects in lysosome function. & $\begin{array}{l}\text { Increased autophagy or defects in completing autophagy result in the accumulation } \\
\text { of autophagosomes that impair cellular functions. }\end{array}$ \\
\hline Immunity & Cellular defense against invasion by bacteria and viruses. & $\begin{array}{l}\text { May allow microbial pathogens to replicate their nucleic acids and supplies } \\
\text { nutrients for growth. }\end{array}$ \\
\hline
\end{tabular}


는 tau 단백질, 루게릭병에서의 $\mathrm{Cu}-\mathrm{ZnSOD}$ 의 돌연변이가 그 예이 다[33]. Atg7이 결핍된 마우스에서는 신경세포의 기능이상과 세포 사멸이 일어난다. 자식작용은 이러한 단백질 응집의 해소뿐만 아니 라 신경세포의 항상성을 유지시켜줌으로써 세포를 보호한다[34]. 또한 신경변성질환 환자의 뇌조직에서도 자기소화액포(autophagic vacuole)가 축적되어 있음이 보고되어 있다[32]. 알츠하이머병에서 presenilin-1 단백질의 돌연변이는 자가포식소포체의 성숙과 리소 좀을 통한 분해능을 억제하며, presenilin-1 단백질의 손실은 자가 포식소포체의 산성화를 방해하여 단백질 분해능을 방해한다[35].

\section{2) 암에서의 자식작용}

자식작용은 종양형성에서 두 가지 역할을 담당한다. 첫째는 종 양억제자로서의 세포사멸유도이고, 둘째는 종양형성기전에서의 세포사멸억제이다[36]. 종양형성의 주요원인은 방사능과 산화적 스트레스, 노화 등의 요소로부터 기인하는 DNA 손상과 돌연변이 이다. 미토콘드리아 DNA는 복구기전과 히스톤 단백질에 의한 보 호의 부족으로 손상에 보다 취약하다[36]. 미토콘드리아는 전자전 달계 활동의 부산물로 다량의 활성산소를 발생시킬 수 있으며 이러 한 활성산소의 조절 부재는 미토콘드리아 DNA를 손상시키고 내막 과 외막의 산화를 초래할 수 있다[11]. 또한 미토콘드리아의 기능장 애는 보다 많은 활성산소를 축적시켜 그 결과 세포의 산화적 스트 레스와 다른 미토콘드리아의 손상을 일으킨다. 자식작용은 손상된 미토콘드리아를 제거하여 산화적 스트레스를 완화시킴으로써 발 암현상을 억제한다[36]. 한편, 종양형성에서 자식작용은 제한적 영 양상태와 저산소 상태에서 그리고 방사능 노출 등에서 손상단백질 과 세포소기관을 제거함으로써 암세포를 생존시킬 수 있다[1].

\section{3) 당뇨병에서의 자식작용}

당뇨병은 췌장 $\beta$ 세포의 기능장애와 인슐린저항성에 의해 발생 한다. 산화적 스트레스가 유발한 미토콘드리아의 기능장애는 당뇨 병의 발전에 중요한 역할을 담당하며 손상된 미토콘드리아는 자식 작용에 의해 제거된다. Atg7'마우스는 췌장 $\beta$ 세포의 급격한 감소 를 보이며 이에 따라 인슐린분비량의 감소를 나타낸다. 또한, Atg7 돌연변이 마우스는 저인슐린혈증과 과혈당증를 나타낸다[37]. 췌 장 $\beta$ 세포의 기능장애에 이어 자식작용의 기능장애는 인슐린저항 성과 연관되어 있다[38]. 소포체스트레스는 인슐린수용체의 세포 막발현을 약화시켜 인슐린저항성을 일으킨다. 인슐린저항성은 순 환적으로 자식작용을 억제하여 결국 기능장애 상태의 단백질과 미토콘드리아 등의 세포소기관의 분해를 방해하여 췌장 $\beta$ 세포의 사멸을 유도하게 된다[39]. 따라서 자식작용은 췌장 $\beta$ 세포의 기능 과 세포항상성에 중요한 기전이며 인슐린감수성에 영향을 미칠 수 있다. 노화의 경우에도 당내성과 연관이 있기 때문에 자식작용의 활성은 노화와도 밀접한 연관이 있을 것으로 사료된다.

\section{4) 심혈관계질환에서의 자식작용}

정상적인 심혈관계 기능을 위해 자식작용은 반드시 필요한 세포 기전이나 비정상적인 자식작용은고혈압과 심장기능부전을 일으킬 수 있다. 심근질환의 하나인 다논병(danon disease)의 경우, 자가포 식소포체와 리소좀의 결합에 관여하는 LAMP-2 단백질의 결핍에 의해 일어난다[40]. 심혈관계질환 관련 질병모델에서 자식작용은 병리학적 조건에 따라 세포보호 또는 세포사멸의 효과를 나타낸 다. 관상동맥혈전증에서 심장근육세포는 자식작용을 일으킨다 [41]. 교차대동맥협착(transverse aortic constriction, TAC) 모델에 서 Atg5 단백질의 결핍은 세포사멸을 증가시키나 Beclin1 단백질의 결핍은 심장기능의 악화로부터 세포를 보호한다. 즉, Beclin1은 Bcell lymphoma 2 (Bcl-2) 단백질과 상호작용하여 항 아폽토시스효 과를 억제하여 세포사멸을 유도한다[42]. 파킨슨병 연관유전자로 알려진 Parkin은 p62와의 상호작용을 통해 심장에서 미토콘드리 아 특이적 자식작용을 일으킨다[43].

\section{5) 염증반응에서의 자식작용}

자식작용은 선천성면역반응의 중요한 요소이며 적응성면역반 응에서도 다양한 기능을 담당하고 있다[44]. 자식작용은 자가포식 용해소체 경로를 통해 침입한 병원체의 성장을 제한한다. 세균 그 리고 바이러스, 기생충 등은 자식작용의 표적이다[45]. 자식작용은 특정 단일가닥 RNA 바이러스의 탐색을 가능하게 한다. 이 과정에 서 엔도좀내로 이동된 바이러스복제중개체는 병원체형태인식수 용체(pathogen pattern-recognition receptor, PRR)와 TLR7에 의 해 인지된다. 또한 자식작용은 전 염증시토카인의 생성과 관련이 있다. 형질세포양수지상세포(plasmacytoid dendritic cell, pDC)에 서 자식작용은 제 1 형 인터페론(infection-initiated type I interferon, IFN)의 생성에 필요한 기전이다[46]. 그러나 ATG5 결핍 마우스 의 배아 섬유아세포는 단일가닥 RNA 바이러스의 감염에 대해 제 1 형 인터페론의 생성을 촉진하였으며, 이 경우에는 자식작용이 시 토카인의 생성을 억제한다는 것을 보여준다[47]. 따라서 자식작용 은 선천성면역반응에서 전 염증반응과 항 염증반응에서 두 가지 상반되는 역할을 담당한다.

자식작용은 항원제시에서 면역세포의 발생과 활성화, 성숙의 단 계에 이르기까지 다양한 방법으로 적응성면역반응에 참여한다. 자 식작용은 $\mathrm{CD}^{+} \mathrm{T}$ 면역세포 항원제시에 대해 class II 주조직적합복 합체로 항원을 전달한다[48]. 또한, Atg5 결핍 마우스의 경우, $\mathrm{T}$ 면 역세포와 B 면역세포의 발달이 억제되어 있어 자식작용이 면역세 포증식과 발달에 중요한 역할을 담당한다는 것을 알 수 있다[49]. 뿐만 아니라 자식작용은 $\mathrm{T}$ 면역세포의 선택과 내성기전에서 흥선 상피세포에서 지속적으로 일어난다고 보고되어 있다[50]. 이로써 자식작용은 적응성면역반응에서 필수적인 세포 내 기전이라고 말 할수 있다. 


\section{결 론}

자식작용은 세포와 개체의 항상성에서 중요한 집합적인 생물학 적 기전의 하나이며, 다수의 유전자에 의해 조절된다. 본 논문에서 는 활성산소의 준위와 이에 따른 산화환원신호가 자식작용과 어떻 게 관여되어 있는지 그리고 다양한 질병과 어떤 상호작용을 하는 지 살펴보았다. 이러한 과정에서 자식작용은 세포를 보호하기도 하 고 세포사멸을 유도하기도 한다. 이러한 현상은 산화환원신호와의 연계성에서 매우 주목되고 있다. 산화적 스트레스는 높은 반응성 의 특성 때문에 독성물질로 귀결되는 활성산소에 의한 것이다. 자 식작용은 이러한 산화적 스트레스에 의해 기능을 할 수 없는 세포 를 ‘자가포식'의 기전으로 사멸시키지만, 이는 '자가청소'의 의미에 서 개체에 이롭다고 말할 수 있다. 활성산소에 대한 급속한 반응은 세포 내 환경변화에 대한 급속한 적응이며 산화환원신호에 반응하 여 세포를 보호하거나 사멸시키는 자식작용의 개체 내의 균형적 역 할은 보다 연구되어야 할 영역이라 할 수 있겠다.

결론적으로 활성산소의 형성은 정상적인 세포생리학적 현상이 나, 과도한 또는 비정상적인 활성산소의 생성은 산화적 스트레스로 나타나 결국 신경변성질환 그리고 암, 당뇨병, 염증반응 등과 같은 다양한 질병으로 진행된다. 자식작용을 단순히 활성산소에 의한 단백질 및 세포소기관의 손상을 감지하고 이를 제거하는 기전으 로 분류하려는 경향이 있으나, 다양한 세포 내 위치에서 발생하는 활성산소와의 관계에 대한 실험적 증거는 아직 미미하다. 자식작용 의 신호경로에서 다양한 특이적 활성산소와의 연구는 세포생물학 그리고 관련된 질병의 연구에 매우 중요한 토대가 될 것이다.

\section{REFERENCES}

1. Cuervo AM. Autophagy: in sickness and in health. Trends Cell Biol 2004; 14:70-7.

2. Levine B, Klionsky DJ. Development by self-digestion: molecular mechanisms and biological functions of autophagy. Dev Cell 2004;6:463-77.

3. Sridhar S, Botbol Y, Macian F, Cuervo AM. Autophagy and disease: always two sides to a problem. J Pathol 2012;226:255-73.

4. Shacka JJ, Roth KA, Zhang J. The autophagy-lysosomal degradation pathway: role in neurodegenerative disease and therapy. Front Biosci 2008;13: 718-36.

5. Gottlieb RA, Carreira RS. Autophagy in health and disease. 5. Mitophagy as a way of life. Am J Physiol Cell Physiol 2010;299:C203-10.

6. He C, Klionsky DJ. Regulation mechanisms and signaling pathways of autophagy. Annu Rev Genet 2009;43:67-93.

7. Chen Y, Klionsky DJ. The regulation of autophagy - unanswered questions. J Cell Sci 2011;124:161-70.

8. Kabeya Y, Mizushima N, Ueno T, Yamamoto A, Kirisako T, Noda T, et al. LC3, a mammalian homologue of yeast Apg8p, is localized in autophagosome membranes after processing. EMBO J 2000;19:5720-8.

9. Bjorkoy G, Lamark T, Brech A, Outzen H, Perander M, Overvatn A, et al. p62/SQSTM1 forms protein aggregates degraded by autophagy and has a protective effect on huntingtin-induced cell death. J Cell Biol 2005;
171:603-14.

10. Gueraud F, Atalay M, Bresgen N, Cipak A, Eckl PM, Huc L, et al. Chemistry and biochemistry of lipid peroxidation products. Free Radic Res 2010; 44:1098-124.

11. Murphy MP. How mitochondria produce reactive oxygen species. Biochem J 2009;417:1-13.

12. Scherz-Shouval R, Shvets E, Fass E, Shorer H, Gil L, Elazar Z. Reactive oxygen species are essential for autophagy and specifically regulate the activity of Atg4. EMBO J 2007;26:1749-60.

13. Inoki K, Zhu T, Guan KL. TSC2 mediates cellular energy response to control cell growth and survival. Cell 2003;115:577-90.

14. Kim J, Kundu M, Viollet B, Guan KL. AMPK and mTOR regulate autophagy through direct phosphorylation of Ulk1. Nat Cell Biol 2011;13:13241.

15. Egan DF, Shackelford DB, Mihaylova MM, Gelino S, Kohnz RA, Mair W, et al. Phosphorylation of ULK1 (hATG1) by AMP-activated protein kinase connects energy sensing to mitophagy. Science 2011;331:456-61.

16. Emerling BM, Weinberg F, Snyder C, Burgess Z, Mutlu GM, Viollet B, et al. Hypoxic activation of AMPK is dependent on mitochondrial ROS but independent of an increase in AMP/ATP ratio. Free Radic Biol Med 2009; 46:1386-91.

17. Alexander A, Cai SL, Kim J, Nanez A, Sahin M, MacLean KH, et al. ATM signals to TSC2 in the cytoplasm to regulate mTORC1 in response to ROS. Proc Natl Acad Sci U S A 2010;107:4153-8.

18. Sims GP, Rowe DC, Rietdijk ST, Herbst R, Coyle AJ. HMGB1 and RAGE in inflammation and cancer. Annu Rev Immunol 2010;28:367-88.

19. Tang D, Kang R, Cheh CW, Livesey KM, Liang X, Schapiro NE, et al. HMGB1 release and redox regulates autophagy and apoptosis in cancer cells. Oncogene 2010;29:5299-310.

20. Bellot G, Garcia-Medina R, Gounon P, Chiche J, Roux D, Pouyssegur J, et al. Hypoxia-induced autophagy is mediated through hypoxia-inducible factor induction of BNIP3 and BNIP3L via their BH3 domains. Mol Cell Biol 2009;29:2570-81.

21. Byun YJ, Kim SK, Kim YM, Chae GT, Jeong SW, Lee SB. Hydrogen peroxide induces autophagic cell death in C6 glioma cells via BNIP3-mediated suppression of the mTOR pathway. Neurosci Lett 2009;461:131-5.

22. Li Y, Wang Y, Kim E, Beemiller P, Wang CY, Swanson J, et al. Bnip3 mediates the hypoxia-induced inhibition on mammalian target of rapamycin by interacting with Rheb. J Biol Chem 2007;282:35803-13.

23. Hanna RA, Quinsay MN, Orogo AM, Giang K, Rikka S, Gustafsson AB. Microtubule-associated protein 1 light chain 3 (LC3) interacts with Bnip3 protein to selectively remove endoplasmic reticulum and mitochondria via autophagy. J Biol Chem 2012;287:19094-104.

24. Wasserman WW, Fahl WE. Functional antioxidant responsive elements. Proc Natl Acad Sci U S A 1997;94:5361-6.

25. Ishii $\mathrm{T}$, Itoh $\mathrm{K}$, Yamamoto M. Roles of Nrf2 in activation of antioxidant enzyme genes via antioxidant responsive elements. Methods Enzymol 2002;348:182-90

26. Itoh K, Wakabayashi N, Katoh Y, Ishii T, Igarashi K, Engel JD, et al. Keap1 represses nuclear activation of antioxidant responsive elements by Nrf2 through binding to the amino-terminal Neh2 domain. Genes Dev 1999; 13:76-86.

27. Li PF, Dietz R, von Harsdorf R. p53 regulates mitochondrial membrane potential through reactive oxygen species and induces cytochrome c-independent apoptosis blocked by Bcl-2. EMBO J 1999;18:6027-36

28. Bensaad K, Tsuruta A, Selak MA, Vidal MN, Nakano K, Bartrons R, et al. TIGAR, a p53-inducible regulator of glycolysis and apoptosis. Cell 2006; 126:107-20.

29. Bensaad K, Cheung EC, Vousden KH. Modulation of intracellular ROS 
levels by TIGAR controls autophagy. EMBO J 2009;28:3015-26.

30. Crighton D, Wilkinson S, O’Prey J, Syed N, Smith P, Harrison PR, et al. DRAM, a p53-induced modulator of autophagy, is critical for apoptosis. Cell 2006;126:121-34.

31. Budanov AV. Stress-responsive sestrins link p53 with redox regulation and mammalian target of rapamycin signaling. Antioxid Redox Signal 2011;15:1679-90.

32. McCray BA, Taylor JP. The role of autophagy in age-related neurodegeneration. Neurosignals 2008;16:75-84.

33. Gal J, Strom AL, Kwinter DM, Kilty R, Zhang J, Shi P, et al. Sequestosome 1/p62 links familial ALS mutant SOD1 to LC3 via an ubiquitin-independent mechanism. J Neurochem 2009;111:1062-73.

34. Hara T, Nakamura K, Matsui M, Yamamoto A, Nakahara Y, Suzuki-Migishima R, et al. Suppression of basal autophagy in neural cells causes neurodegenerative disease in mice. Nature 2006;441:885-9.

35. Lee JH, Yu WH, Kumar A, Lee S, Mohan PS, Peterhoff CM, et al. Lysosomal proteolysis and autophagy require presenilin 1 and are disrupted by Alzheimer-related PS1 mutations. Cell 2010;141:1146-58.

36. Jin S. Autophagy, mitochondrial quality control, and oncogenesis. Autophagy 2006;2:80-4.

37. Jung HS, Chung KW, Won Kim J, Kim J, Komatsu M, Tanaka K, et al. Loss of autophagy diminishes pancreatic beta cell mass and function with resultant hyperglycemia. Cell Metab 2008;8:318-24.

38. Petersen KF, Dufour S, Befroy D, Garcia R, Shulman GI. Impaired mitochondrial activity in the insulin-resistant offspring of patients with type 2 diabetes. N Engl J Med 2004;350:664-71.

39. Jung HS, Lee MS. Role of autophagy in diabetes and mitochondria. Ann N Y Acad Sci 2010;1201:79-83.

40. Nishino I, Fu J, Tanji K, Yamada T, Shimojo S, Koori T, et al. Primary LAMP-2 deficiency causes X-linked vacuolar cardiomyopathy and myopa- thy (Danon disease). Nature 2000;406:906-10.

41. Zhu H, Tannous P, Johnstone JL, Kong Y, Shelton JM, Richardson JA, et al. Cardiac autophagy is a maladaptive response to hemodynamic stress. J Clin Invest 2007;117:1782-93.

42. Nakai A, Yamaguchi O, Takeda T, Higuchi Y, Hikoso S, Taniike M, et al. The role of autophagy in cardiomyocytes in the basal state and in response to hemodynamic stress. Nat Med 2007;13:619-24.

43. Huang C, Andres AM, Ratliff EP, Hernandez G, Lee P, Gottlieb RA. Preconditioning involves selective mitophagy mediated by Parkin and p62/ SQSTM1. PLoS One 2011;6:e20975.

44. Deretic V. Multiple regulatory and effector roles of autophagy in immunity. Curr Opin Immunol 2009;21:53-62.

45. Orvedahl A, Levine B. Eating the enemy within: autophagy in infectious diseases. Cell Death Differ 2009;16:57-69.

46. Lee HK, Lund JM, Ramanathan B, Mizushima N, Iwasaki A. Autophagydependent viral recognition by plasmacytoid dendritic cells. Science 2007; 315:1398-401.

47. Jounai N, Takeshita F, Kobiyama K, Sawano A, Miyawaki A, Xin KQ, et al. The Atg5 Atg12 conjugate associates with innate antiviral immune responses. Proc Natl Acad Sci U S A 2007;104:14050-5.

48. Dengjel J, Schoor O, Fischer R, Reich M, Kraus M, Muller M, et al. Autophagy promotes $\mathrm{MHC}$ class II presentation of peptides from intracellular source proteins. Proc Natl Acad Sci U S A 2005;102:7922-7.

49. Miller BC, Zhao Z, Stephenson LM, Cadwell K, Pua HH, Lee HK, et al. The autophagy gene ATG5 plays an essential role in B lymphocyte development. Autophagy 2008;4:309-14.

50. Nedjic J, Aichinger M, Emmerich J, Mizushima N, Klein L. Autophagy in thymic epithelium shapes the T-cell repertoire and is essential for tolerance. Nature 2008;455:396-400. 